Neurologijos seminarai 2020; 24(86): 291-298

DOI: $10.29014 /$ ns.2020.37

\title{
Neurofilamentų lengvosios grandinès vaidmuo neurologinių ligų kontekste
}

\author{
V. Taluntiené* \\ R. Motiekaitytė** \\ R. Kizlaitiené* \\ N. Giedraitiené* \\ G. Kaubrys* \\ *Vilniaus universitetas, \\ Medicinos fakultetas, Klinikines \\ medicinos institutas, Neurologijos \\ ir neurochirurgijos klinika \\ **Vilniaus universitetas, \\ Medicinos fakultetas
}

\begin{abstract}
Santrauka. Neurofilamentų lengvoji grandinè (NFL) yra struktūrinis neuronų citoplazmos baltymas. Daugiausia jo randama dideliuose mielinizuotuose aksonuose. İvykus aksonų pažeidimui, dideja NFL koncentracija smegenų skystyje ir kraujyje, todèl tai gali būti jautrus ịvairių, ypač neurodegeneracijos ir uždegimo sukeltų, neurologinių ligų žymuo. Tobulèjant NFL koncentracijos kraujyje matavimo metodikoms, atsiveria galimybès stebėti jos dinamiką susirgimo eigoje, vertinti atsaką ị gydymą. Daugẻja duomenų, kad NFL gali būti ir naudingas prognostinis rodiklis. Šiame apžvalginiame straipsnyje pateikiami literatūros duomenys apie NFL tyrimus ir reikšmę demencijų, šoninės amiotrofinès sklerozės, su ŽIV asocijuotų neurokognityvinių sutrikimų, išsėtinès sklerozės ir kitų ligų kontekste.
\end{abstract}

Raktažodžiai: neurofilamentų lengvoji grandinè, aksonų pažeidimas, neurodegeneracinès ligos, išsètinè sklerozè.

\section{IVADAS}

Neurofilamentų lengvoji grandinè (NFL) - tai neuronų citoskeleto baltymas, ekspresuojamas mielinizuotų neuronų citoplazmoje [1]. Tyrimų duomenys rodo, kad NFL koncentracija likvore ir serume padideja sergant ligomis, kuriu patogenezèje vyrauja aksonų pažeidimas ar neurodegeneracija. NFL koncentracija koreliuoja su aksonų pažeidimo mastu, todèl gali būti ne tik kiekybinis ligos vertinimo žymuo, bet ir potencialus prognostinis neurologinių ligų rodiklis. Taip pat tikimasi, kad didejjančios galimybès išmatuoti NFL koncentraciją kraujyje leistų monitoruoti ligos aktyvumą ir atsaką į gydymą.

\section{NEUROFILAMENTŲ STRUKTŪRA IR FUNKCIJOS}

Neurofilamentai (NF) yra $10 \mathrm{~nm}$ skersmens cilindriniai baltymai, randami tik neuronų citoplazmoje: dendrituose, neuronų kūnuose, o daugiausia - aksonuose. NF stabilizuoja neurono struktūrą, lemia aksono storẻjimą ir didina laidumo greiti. Storuose mielinizuotuose aksonuose NF randama daugiausia [2].

Lyginant su kitais struktūriniais baltymais, NF yra didesni už aktiną $(6 \mathrm{~nm})$, bet mažesni už mioziną $(15 \mathrm{~nm})$. NF skiriasi molekulès svoriu, pagal kurị skirstomi ị subvienetus: neurofilamentų lengvają grandinę (angl. neurofilament light chain, NFL) ( $\sim 68 \mathrm{kDa})$, vidutiniają grandinę (angl. neurofilament medium chain, NFM) $(\sim 145 \mathrm{kDa})$, sunkiają grandinę (angl. neurofilament heavy chain, NFH) ( $200 \mathrm{kDa})$ ir $\alpha$-interneksinus [2]. NFL sudaro neurofilamentų „stuburą“, o NFH ir NFM - šonines atšakas $[3,4]$.

İprastomis sąlygomis iš aksonų i tarpląstelinị tarpą nuolat išskiriami nedideli NFL kiekiai, vèliau patenkantys ị smegenų skystị (SS). Dèl traumos, neurodegeneracijos, uždegimo ar kraujagyslių patologijos įvykus centrinès nervų sistemos (CNS) aksonų pažeidimui, suyra jų membra-

(C) Neurologijos seminarai, 2020. Open Access. This article is distributed under the terms of the Creative Commons Attribution 4.0 International License CC-BY 4.0 (http://creativecommons.org/licenses/by/4.0/), which permits unrestricted use, distribution, and reproduction in any medium, provided you give appropriate credit to the original author(s) and the source, provide a link to the Creative Commons license, and indicate if changes were made. 
na, pažeidžiamas citoskeleto vientisumas ir NF išskyrimas ị smegenų skystị smarkiai padidejja. Dėl šios savybès neurofilamentai laikomi galimais nespecifinio aksonų pažeidimo biožymenimis ir yra plačiai tyrinèjami neurodegeneracinių ligų kontekste. Intensyviausiai tyrinėjama NF lengvoji grandinė: jos aksonuose randama daugiausia, ji geriausiai tirpsta smegenu skystyje ir kraujyje, todèl jos koncentracijos organizmo skysčiuose matavimas laikomas patikimiausiu. NFL koncentracija SS didèja su amžiumi $[5,6]$. Vienoje apžvalgoje nurodoma, kad NFL viršutinè normos riba nuo 20 iki 50 metų padidèja apie 2,5 karto ir dar padvigubejja sulaukus 70 metų [6].

Nors NF yra specifiški neuronams, mažesnị jų kiekį galima nustatyti ir kraujo serume, kur jie patenka smegenu skysčiui drenuojantis ị veninị kraują arba dèl difuzijos pro hematoencefalinị barjerą [7]. Kraujyje NFL koncentracija yra keliasdešimt kartų mažesnè nei SS [8].

\section{NF LABORATORINE் DIAGNOSTIKA}

NF tyrimai per pastaruosius tris dešimtmečius išgyveno gana dramatišką evoliuciją. Pirmos kartos imunofermentiniai metodai buvo pusiau kokybiniai, tačiau jų metu būdavo dèsningai aptinkama įvairių NF izoformų neurologinių pacientų SS ir kraujyje. Atliekant antros kartos ELISA imunofermentinius tyrimus, likvore buvo gaunami tikslesni rezultatai, kurie gerokai paspartino NFL tyrinėjimą. Tačiau SS tyrimų trūkumas yra jų invazyvumas: norint stebèti atsaką i gydymą, reikalingos pakartotinès juosmeninės punkcijos. Matavimams kraujyje ELISA metodas yra nepakankamai jautrus [5]. Trečios kartos elektrochemiliuminescencijos (ECL) technologija pasižymi didesniu jautrumu, šiam tyrimui reikalingi maži mėginių kiekiai.

Ketvirtos kartos SIMOA (angl. single molecule array) technologija yra net 126 kartus jautresnė už ELISA ir 25 kartus jautresnè už ECL technologiją [5]. Taikant šį metodą, naudojami standartiniai ELISA reagentai, tačiau gauti imuniniai kompleksai izoliuojami ant mažų paramagnetinių dalelių. Kiekviena dalelè vẻliau patenka ị „šulinėlị“, kurio tūris matuojamas femtolitrais, ir ten gali būti individualiai nuskaitoma. Ši technologija patikimai nustato itin žemą NFL koncentraciją jaunų sveikų žmonių kraujyje, todèl ja galima stebėti net ir nežymius koncentracijos svyravimus, lengviau nustatyti ribą tarp normos ir patologijos [5]. Komerciškai prieinami yra NFL ir fosforilinto NFH (pNFH) rinkiniai (NFM tyrinètas labai menkai) [3]. Dèl šio tyrimo atsiradimo gali reikšmingai paspartèti NFL matavimų kraujyje įdiegimas ị klinikinę praktiką ligos atsako ị gydymą monitoravimui.

\section{NFL IR DEMENCIJOS}

1999 m. nustatyta, kad pacientų, sergančių kraujagysline demencija, Alzheimerio liga (AL) ir ypač frontotemporaline demencija (FTD), NFL koncentracija likvore yra aukš- tesnè nei sveikos kontrolinès grupès [9]. Metaanalizès duomenimis, FTD sergančiųjų NFL koncentracijos yra reikšmingai aukštesnès nei asmenų su kitomis demencijomis [10].

Iš FTD spektro susirgimų, pirminių progresuojančių afazijų (PPA) atvejais randama didžiausia SS NFL koncentracija, palyginus su AL. Serumo NFL gali būti naudingas PPA diferencinėje diagnostikoje: pacientams su nesklandžiosios ir semantinès afazijos variantais randamos aukštesnès NFL vertès nei pacientams su logopeniniu variantu, kuris dabar priskiriamas Alzheimerio ligai [11]. SS ir serumo NFL vertės koreliuoja su klinikine ligos progresija, išgyvenimo prognoze ir smegenų, ypač frontalinès skilties, tūrio mažèjimu visiems pacientams su pirminėmis progresuojančiomis afazijomis [11].

Kalbant apie Alzheimerio ligą, SS NFL, kartu su tradiciniais AL žymenimis (t-tau, p-tau, A $\beta 42$ ), patikimai atskiria sergančiuosius tiek ankstyvaja ir vèlyvaja $\mathrm{AL}$, tiek lengvu kognityviniu sutrikimu (LKS; angl. mild cognitive impairment) nuo sveikųjų [9, 12]. Reikšmingai tarp šių grupių skiriasi ir plazmos / serumo NFL koncentracijos [12]. Kaip ir bendrojoje populiacijoje, didesnès NFL vertės randamos vyresniems pacientams, sergantiems AL [13].

Sergančiujų AL populiacijoje SS ir kraujo NFL vertès tiesiogiai koreliuoja su įvairiais likvoro biožymenimis (t-tau, p-tau, neurograninu ir ị chitinazę panašiu baltymu-1), bet nekoreliuoja su A $\beta 42$ [13]. Manoma, kad A $\beta 42$ lygis atspindi nuo $\beta$-amiloido priklausančią, o NFL - nuo $\beta$-amiloido nepriklausančią (kitų proteinopatijų, kraujagyslinio pažeidimo ir neurouždegimo sukeltą) neurodegeneraciją [14]. Esama duomenų, kad didesnè SS NFL koncentracija yra susijusi su didesne lengvo kognityvinio sindromo (LKS) rizika kognityviškai sveikiems suaugusiesiems, tuo tarpu SS t-tau, p-tau ir neurograninas panašios prognostinès vertès neturi [15].

Matsson ir kt. 4 metus trukusiame tyrime vertino pažintinių funkcijų ir vaizdinių tyrimų dinamiką pacientams su $\mathrm{AL}$ arba MCI. Išmatavus NFL koncentracijas plazmoje, nustatyta neigiama koreliacija su bendrosiomis pažintinèmis ir vykdomosiomis funkcijomis, teigiama koreliacija su smegenų atrofijos požymiais (šoninių skilvelių dydžiu, hipokampo tūriu, žievès storiu) tyrimo pradžioje ir greitesne jų neigiama dinamika [16].

Tiriant AL genetinių mutacijų nešiotojų šeimas, autosominių dominantinių mutacijų nešiotojams rasta serumo NFL koncentracijos koreliacija su prognozuojamu metu iki susirgimo skaičiumi [17]. FTD demencijų grupèje NFL patikimai atskiria sergančiuosius su nustatytomis $M A P T$, $G R N, C 9 o r f 72$ genų mutacijomis nuo besimptomių šių mutacijų nešiotojų. İdomu tai, kad SS NFL 3-4 kartus padidejo besimptomiams nešiotojams, kuriems tyrimo eigoje atsirado pirmieji FTD simptomai (angl. converters) [18].

Ateityje NFL gali būti vertingas žymuo, padedantis atskirti demencijas nuo ne neurodegeneracinių, o kitos kilmès, pavyzdžiui, psichiatrinès etiologijos, būklių. NFL taip pat galètų prisidèti prie FTD ir AL diferencinès diag- 
nostikos ankstyvose stadijose, kombinuojant su klinikiniu įvertinimu ir kitais žymenimis. Kitas potencialus NFL pritaikymas demencijų srityje - pacientų su didesne kognityvikos blogejjimo rizika ar mutacijų nešiotojų preklinikinèse FTD ir AL stadijose atranka ị klinikinius vaistų tyrimus ir atsako ị gydymą stebejjimas [2].

\section{ŠONINE் AMIOTROFINĖ SKLEROZE்}

Šoninė amiotrofinė sklerozė (ŠAS) - progresuojanti neurodegeneracinè liga, pažeidžianti motorinius neuronus. Nustatyta, kad sergančiųų ŠAS likvoro pNFH [19] ir NFL [20,21] vertès yra reikšmingai didesnès nei sveikųjų ir yra vienos didžiausių tarp visų neurologinių susirgimų. NFL vertès SS ryškiai koreliuoja su vertemis kraujyje [20], kai duomenys apie pNFH yra nevienareikšmiai [22].

İvairių tyrimų duomenimis, abiejų NF subvienetų koncentracija organizmo skysčiuose patikimai atskiria ŠAS nuo ją imituojančių (angl. disease mimics) ir kitų neurologinių ligų [23, 24], tačiau SS pNFH yra jautresnis ir specifiškesnis rodiklis nei NFL [20,25]. Dar viename tyrime didesnès SS NF vertès rastos palyginus ŠAS su neūmiomis neuždegiminėmis ligomis, tačiau skirtumo nebuvo lyginant su ūmių-poūmių uždegiminių ir onkologinių ligų grupe. Autorių nuomone, ūmios ar poūmès uždegiminès ar onkologinès ligos taip pat sukelia reikšmingą neuronų žūtị ir neurodegeneraciją [26].

Duomenys dèl NF koncentracijų motorinio neurono ligų grupejje yra nevienareikšmiai [24]. Randamas reikšmingas ryšys tarp likvoro NF verčių ir viršutinio bei apatinio motorinio neurono pažeidimo apimtų sričių [23]. Taip pat pastebėta tendencija, kad didesnès SS NFL vertès randamos viršutini motorinị neuroną pažeidžiančiuose ligos potipiuose (klasikinė ŠAS, progresuojantis bulbarinis paralyžius, ŠAS su viršutinio motoneurono dominavimu), mažesnès - esant suglebusios galūnès sindromui ar progresuojančiai raumenų atrofijai [21].

Ir pNFH, ir NFL koreliuoja su motoneuronų pažeidimo mastu, tačiau pNFH geriau parodo apatinio motoneurono pažeidimą, o NFL - viršutinio [24]. Viename tyrime nustatyta, kad likvoro NFL lygis koreliuoja su piramidinio laido pakenkimu magnetinio rezonanso difuzijos tenzoriaus vaizdinimo (angl. diffusor tensor imaging, DTI) režime [27].

Irodyta, kad NF koreliuoja su ALS sunkumu, ivertintu pagal peržiūrètą ŠAS sunkumo vertinimo skalę (angl. Revised Amyotrophic Lateral Sclerosis Functional Rating Scale, ALSFRS-R), ir ligos progresavimo greičiu [24], greitesniu generalizacijos greičiu (angl. time to generalization, TTG). Pavyzdžiui, NFL koncentracijos padidejimas $1000 \mathrm{ng} / \mathrm{l}$ nuo ankstesnio lygio buvo susijęs su $28 \%$ didesne ŠAS generalizacijos rizika [28]. Tiek pNFH, tiek NFL ligos pradžioje yra nepriklausomi išgyvenamumo biomarkeriai: aukštesnès NF koncentracijos koreliuoja su trumpesniu išgyvenamumu [21, 24, 29].
ŠAS dažniausiai diagnozuojama jau pažengusioje stadijoje, vidutiniškai praejus 10-12 mèn. nuo ligos pasireiškimo. NFL SS ir kraujyje bei pNFH SS padaugėja anksti ligos pradžioje [25]. Esama duomenų, kad, nors besimptomių SOD1 mutacijų nešiotojų NFL koncentracijos nesiskyrè nuo sveikų tiriamųų, jos padideja keliais mėnesiais (iki metų) anksčiau, nei manifestuoja simptomai [30].

NF kitimas dinamikoje galimai priklauso nuo ligos eigos - asmenų, sergančių greitai progresuojančia ligos forma, koncentracijos ligos pradžioje būna didelès ir palaipsniui mažèja (mažèjant nepažeistų motoneuronų skaičiui). Lètų progresuotojų NF vertès gali didèti dinamikoje arba likti ganètinai stabilios ilgą laiką [22, 29].

NF galètų būti vertingas diagnostinis rodiklis, diferencijuojant ŠAS nuo kitų ligų, net ir ankstyvose stadijose bei prognostinis žymuo ligos pažeidimo apimčiai ir progresavimo greičio numatymui. Teoriškai NF koncentraciją ligos pradžioje būtų galima naudoti pacientu stratifikavimui, ịtraukiant ị klinikines studijas, tačiau dèl ịvairios ligos eigos gali būti sunku vertinti atsaką ị gydymą [29]. Visgi prieš taikant šiuos tyrimus klinikinejje praktikoje, reikalinga naudojamų medžiagų ir metodikų standartizacija ir validizacija [2].

\section{SU ŽIV SUSIJĘ NEUROKOGNITYVINIAI SUTRIKIMAI}

Neurokognityviniai sutrikimai (angl. HIV-associated neurocognitive disorders, HAND), taikant antiretrovirusinę terapiją, randami iki 50 \% ŽIV sergančių asmenų ir yra susiję su trumpesniu ligonių išgyvenamumu. HAND sutrikimų spektras labai įvairus - nuo besimptomio ir lengvo neurokognityvinio sutrikimo iki su ŽIV susijusios demencijos (angl. HIV associated dementia, HAD), pasireiškiančios 2-8 \% sergančiujų [31, 32].

Daugelio studijų duomenimis, ŽIV(+) tiriamujų likvoro ir kraujo NFL vertès yra reikšmingai didesnès nei ŽIV(-) asmenų ir koreliuoja tarpusavyje (koncentracija kraujyje yra daug mažesnè) $[10,33]$. Taip pat randama koreliacija tarp SS NFL koncentracijos ir plazmos viremijos, galimai rodanti ryši tarp sisteminès infekcijos sunkumo ir neurodegeneracijos [32]

Duomenys apie pirminę ŽIV infekciją yra nevienareikšmiai: viename tyrime padidèjęs NFL lygis rastas tik $3 \%$, o kitame - net $44 \%$ sergančiujjų ankstyva ŽIV infekcija $[33,34]$. Tokie radiniai gali būti susiję su tyrimo laiku po užsikrètimo; tikėtina, kad neuronų pažeidimas įvyksta ankstyvoje ligos stadijoje, bet ne pirmomis ligos dienomis [6].

Lètinès negydytos ŽIV infekcijos atveju, kai nėra neurokognityvinio sutrikimo, taip pat randamas NFL padidejimas likvore, rodantis subklinikinį neuronų pažeidimą. Mažejjant CD4+ limfocitų kiekiui, vis didesnei daliai pacientų randama padidejjusi SS NFL koncentracija atsižvelgiant i amžių [32, 34, 35]. Kai CD4+ limfocitų skaičius tampa 
mažesnis nei $50 / \mathrm{mm}^{3}$, SS NFL padidejjimas randamas net $75 \%$ neurologiškai besimptomių pacientų [35].

Vertinant natūralią ligos eigą, ŽIV demencija sergančių pacientų NFL lygiai yra didžiausi - medianos daugiau nei 10 kartų didesnès nei kontrolinės grupės [6]. Šių pacientų NFL koncentracijos yra didesnès ir lyginant su kitais ŽIV gydytų ir negydytų sergančiųų pogrupiais, išskyrus neurologiškai besimptomius pacientus su CD4+ $<50 / \mathrm{mm}^{3}$ [35]. NFL koncentracija yra didesnè, esant labiau pažengusiai ŽIV demencijai [36]. Sisteminėje apžvalgoje rasta, kad ŽIV demencijos grupejje likvoro NFL koncentracijos yra didžiausios, lyginant su kitais neurologiniais susirgimais [10].

Taikant antiretrovirusinę terapiją, NFL koncentracija mažèja tiek neurologiškai besimptomių pacientų, tiek ŽIV demencijos grupeje, kaip ir plazmos viremija; esama duomenų, kad pagerejja ir neurokognityvinių testų atlikimas $[34,36]$. Nepaisant to, pacientų su viruso supresija SS NFL vis tiek yra šiek tiek didesnis nei nesergančiųu - ši radini bandoma paaiškinti tebesitęsiančia nežymia imunine aktyvacija ir aksonų degradacija, kurią sukelia tolesnè nežymi viruso replikacija CNS [6, 34].

Kadangi NFL - nespecifinis neurodegeneracijos markeris, esant ŽIV infekcijai padidèjęs NFL lygis dažnai būna ne tik sergant HAND, bet yra būdingas ir esant kitoms neurologinėms komplikacijoms, ypač - oportunistinėms CNS infekcijoms. Jų atveju NFL koncentracija gali būti net ŽIV demencijos lygio; didžiausia koncentracija randama pacientams su citomegalovirusiniu (CMV) encefalitu, mažiausia - su kriptokokiniu meningitu. Šie radiniai atitinka histopatologinius radinius - CMV sukelia ryškų nekrotizuojanti periventrikulinị pažeidimą, o kriptokokinė infekcija dažniausiai paveikia tik smegenų dangalus [6, 36].

\section{IŠSĖTINE் SKLEROZE்}

Išsėtinè sklerozė (IS) - autoimuninė CNS liga, kurios viena iš pagrindinių patogenezès grandžių yra aksonų demielinizacija. Dar 1996 m. buvo aprašyta, kad IS sergančiųjų SS NFL koncentracijos reikšmingai skyrèsi nuo sveikos kontrolinės grupės [37]. Tyrinèta ir serumo NFL koncentracija IS pacientų kohortoje, naudojant ketvirtos kartos tyrimus SIMOA - abiejų organizmo skysčių koncentracijos koreliuoja tarpusavyje ir yra didesnès nei tiriamųų, nesergančių IS [5]. Skirtumus nuo sveikų tiriamųų patvirtino neseniai atlikta metaanalizè, tačiau joje pažymima, kad analizuoti tyrimai buvo labai heterogeniški pagal tiriamuju amžių, publikacijų metus ir imčių dydžius [38]. 2019 m. apžvalgoje, remiantis šia metaanalize, pažymima, kad kol kas NF negalètų būti diagnostinis IS kriterijus, kadangi yra per didelis koncentracijų pasiskirstymas ir persipynimas su kitomis neurodegeneracinèmis ligomis [39].

Ligos aktyvumas yra vertinamas klinikinių paūmejjimų skaičiumi ir naujų hiperintensinių T2 režime arba gadolinio kontrastą kaupiančių $(\mathrm{Gd}+)$ židinių skaičiumi. Paste- bėta, kad NFL koncentracija ryškiai didèja paūmėjimo metu, per 2 savaites pasiekia piką ir išlieka panaši 2-3 mėnesius, o po to pamažu grịžta ị bazinị lygi $[38,40]$. Randama reikšminga koreliacija tarp paūmèjimų skaičiaus ir NFL koncentracijos [41]. Ypač didelès NFL vertès randamos po spinalinių paūmėjimų, galimai dèl to, kad nugaros smegenyse yra daug storai mielinizuotų aksonų piramidiniuose laiduose [42].

NFL vertės likvore ir kraujyje yra didesnès pacientams, turintiems daugiau židinių MRT T2 režime ir turintiems Gd+ židinių [40, 43]. Taip pat SS NFL koreliuoja su negalios progresavimu, vertinamu Išplèstine negalios vertinimo skale (angl. Expanded Disability Status Scale, EDSS) [44]. Esama duomenų, kad NFL kiekis padideja jau izoliuoto klinikinio sindromo (IKS; angl. clinically isolated syndrome) metu [44] ir yra didesnis tų asmenų, kurių ligos eiga pasikeite iš IKS ị recidyvuojančią remituojančią (RRIS) ir iš RRIS - į antrinę progresuojančią IS [45]. Literatūroje taip pat randama reikšminga teigiama koreliacija tarp NFL koncentracijos ir smegenų atrofijos ligos eigoje $[43,46]$. Taigi smegenų skysčio NFL gali būti potencialus prognostinis ligos aktyvumo ir neurodegeneracijos žymuo $[45,46]$.

Daugejja duomenų, kad ligos eigą modifikuojanti gydymą ir NFL koncentraciją sieja atvirkštinio ryšio priklausomybè. Gydytiems pacientams randamos mažesnès NFL vertès nei negydytiems [40]. Pacientams su progresuojančia IS NFL koncentraciją likvore sumažino mitoksantrono terapija [10], su RRIS - gydymas natalizumabu [47] ir fingolimodu [43]. SS ir kraujo NFL koncentracija išlieka stabili, kai gydymas keičiamas ị panašaus efektyvumo vaistus, tačiau mažèja, jei pakeičiamas ị efektyvesnius [48] Remiantis šiais duomenimis, NFL ateityje gali tapti naudingu atsako ị gydymą žymeniu. Kol kas nėra žinoma, ar jis būtų efektyvesnis už radiologinị atsako ị gydymą vertinimą. Be to, dar nenustatyta, koks NFL koncentracijos sumažėjimas galètų būti laikomas gero atsako ị gydymą požymiu [39].

\section{HANTINGTONO LIGA}

Hantingtono liga (HL) - progresuojantis neurodegeneracinis susirgimas, sukeltas CAG sekos pasikartojimų skaičiaus padidejjimo HTT gene. Kol kas nèra ịrodymais pagrịsto ligos eigą modifikuojančio gydymo. Sergančiųų HL CNS ir plazmos NFL koncentracija yra didesnè, lyginant su sveikos kontrolinès grupès, ir koreliuoja su UHDRS-TMS (angl. Unified Huntington's Disease Rating Scale Total Motor Score) skalès balais [49, 50] bei smegenų atrofijos žymenimis [51]. Be to, NFL koreliuoja su spejjama ligos manifestacija pagal CAG tripletų skaičių genetinès HL mutacijos nešiotojų grupèje - didesnès NFL vertès randamos net 3-5 m. iki numatomos manifestacijos $[49,50]$. Jeigu šie duomenys bus patvirtinti platesniuose tyrimuose, NF gali būti naudojami kaip antrinių išeičių žymenys klinikiniuose HL tyrimuose [3]. 


\section{PARKINSONO LIGA IR ATIPINIAI PARKINSONINIAI SINDROMAI}

Kliniškai gali būti sunku diferencijuoti Parkinsono ligą (PL) nuo atipinių parkinsoninių sindromų ankstyvose stadijose - dauginės sisteminés atrofijos (MSA), progresuojančio supranuklearinio paralyžiaus (PSP), kortikobazalinès degeneracijos (CBD) ir Lewy kūnelių demencijos (DLB). Irodyta, kad NFL ir NFH koncentracijos ryškiai padidèja sergant PSP, MSA ir CBD. O sergančiųjų PL vertès yra panašios ị sveikos kontrolinès grupès [52].

Didesnès apimties tyrimų duomenimis, SS ir plazmos NFL gerai koreliuoja tarpusavyje ir gali patikimai atskirti PL nuo atipinių sindromų, tačiau nepadètų diferencijuoti tų sindromų tarpusavyje [53]. Šie duomenys atitinka kitų tyrimų rezultatus, kuriuose sergantiems atipiniais sindromais, bet ne PL, rasta reikšmingų baltosios medžiagos pažeidimo požymių [54].

Viename tyrime rastos didesnès PL grupès su demencija NFL vertès plazmoje, lyginant su PL be demencijos, tačiau jos nesiekè AL lygio. Šiame tyrime didesni NFL kiekiai koreliavo su prastesnèmis kognityvinėmis funkcijomis, vertintomis Mini protinès būklès tyrimu (angl. Mini Mental State Examination, MMSE), tačiau nebuvo susiję su motorinių simptomų sunkumu Unifikuotoje Parkinsono ligos vertinimo skaleje (UPDRS) [55].

\section{CREUTZFELDT-JACOB LIGA}

Creutzfeldt-Jacob liga (CJD) yra greitai progresuojantis, prionų sukeliamas neurodegeneracinis susirgimas. Šios ligos atveju randami itin padidejję neurofilamentų kiekiai; didesnè NFL koncentracija siejama su agresyvesne ligos eiga ir trumpesniu išgyvenamumu [56]. SS NFH koncentracija taip pat padidėja tiek sporadinès, tiek genetinès CJD atveju dar prieš simptomų manifestaciją [57]. Visgi NF tyrimo nauda CJD diagnostikoje yra neaiški, kadangi likvoro bendrojo tau (angl. total-tau) koncentracija geriau prognozuoja ligos sunkumą $[4,56]$.

\section{CEREBROVASKULINĖS LIGOS}

Kraujagyslių sistemos pažeidimas gali pasireikšti tiek lètine patologija - kraujagysline demencija, tiek ūmine - galvos smegenų infarktais, išeminiu posthipoksiniu pažeidimu. Kraujagyslinės demencijos atveju reikšmingai padidejja likvoro NFL ir serumo NFH $[9,58]$. İvykus galvos smegenų infarktui, organizmo skysčiuose padidejja abiejų NF subvienetų koncentracija, kuri per 1-3 savaites pasiekia piką ir sumažejja praẻjus 3-6 mėnesiams [59]. Didesnè NFL koncentracija yra susijusi su didesniu infarkto plotu [59]. Po širdies sustojimo sukeltos hipoksijos NF koncentracija kraujyje taip pat padideja ir yra prognostinis ilgalaikès neurologinès prognozès žymuo $[4,60]$.

\section{IŠVADOS}

Per pastaruosius kelerius metus neurofilamentų tyrimai reikšmingai pasistūmèjo ị priekị. NF koncentracijos tyrimai gali padėti įvertinti aksonų pažeidimą įvairių patologinių būklių metu. Nors NF koncentracijos padidejjimas organizmo skysčiuose nèra specifiškas konkrečioms nervų sistemos ligoms, tam tikrais atvejais jis galètų būti diagnostiškai vertingas: ŠAS diferencijuoti nuo ją imituojančių susirgimų, įtarus neurodegeneracinị procesą diferencijuoti AL, FTD, CJD ir kitas greitai progresuojančias demencijas, atskirti PL ir APS ligos pradžioje.

Kaip prognostinị žymenị NF būtų galima naudoti pacientams, sergantiems išsètine skleroze, ligos aktyvumui numatyti ir pasirinkti tinkamiausią ligos eigą modifikuojanti gydymą. NF gali būti vertingas prognozuojant kognityvinị blogéjimą pacientams, sergantiems AL, FTD ir PL, motorinị blogejjimą - pacientams, sergantiems ŠS.

Kad šios naujovès galètų būti įdiegtos ị klinikinę praktiką, reikalinga matavimų standartizacija tarp ịvairių laboratorijų ir analizès metodikų. Norint matuoti NF koncentraciją konkrečiam pacientui, turi būti aiškiai nustatytos amžiaus ir lyties normos, o tam reikalingi plačios apimties normatyviniai populiacijos tyrimai.

NF matavimams kraujyje tampant vis prieinamesniems, atsiveria galimybės nustatinėti NF koncentracijas dinamikoje, stebėti atsaką i gydomąsias intervencijas, kas yra ypač aktualu klinikiniams tyrimams. Ateityje NF rodikliai galètų būti viena iš tyrimų išeičių (angl. outcomes), ypač analizuojant vaistų bioprieinamumą ir efektyvumą, nustatant tinkamą vaistinių medžiagų dozavimą $[2-4,8]$.

\section{Literatūra}

1. Gaetani L, Eusebi P, Mancini A, Gentili L, Borrelli A, Parnetti L, et al. Cerebrospinal fluid neurofilament light chain predicts disease activity after the first demyelinating event suggestive of multiple sclerosis. Mult Scler Relat Disord 2019; 35: 228-32. https://doi.org/10.1016/j.msard. 2019.07.025

2. Gaetani L, Blennow K, Calabresi P, Di Filippo M, Parnetti L, Zetterberg H. Neurofilament light chain as a biomarker in neurological disorders. J Neurol Neurosurg Psychiatry 2019; 90(8): 870-81. https://doi.org/10.1136/jnnp-2018-320106

3. Khalil M, Teunissen CE, Otto M, Piehl F, Sormani MP, Gattringer T, et al. Neurofilaments as biomarkers in neurological disorders. Nat Rev Neurol 2018; 14(10): 577-89. https://doi.org/10.1038/s41582-018-0058-z

4. Gordon BA. Neurofilaments in disease: what do we know? Curr Opin Neurobiol 2020; 61: 105-15. https://doi.org/ 10.1016/j.conb.2020.02.001

5. Disanto G, Barro C, Benkert P, Naegelin Y, Schädelin S, Giardiello A, et al. Serum Neurofilament light: a biomarker of neuronal damage in multiple sclerosis. Ann Neurol 2017; 81(6): 857-70. https://doi.org/10.1002/ana.24954

6. Yilmaz A, Blennow K, Hagberg L, Nilsson S, Price RW, Schouten J, et al. Neurofilament light chain protein as a 
marker of neuronal injury: review of its use in HIV-1 infection and reference values for HIV-negative controls. Expert Rev Mol Diagn 2017; 17(8): 761-70. https://doi.org/ 10.1080/14737159.2017.1341313

7. Reiber H. Proteins in cerebrospinal fluid and blood: barriers, CSF flow rate and source-related dynamics. Restor Neurol Neurosci 2003; 21(3-4): 79-96.

8. Gaiottino J, Norgren N, Dobson R, Topping J, Nissim A, Malaspina A, et al. Increased neurofilament light chain blood levels in neurodegenerative neurological diseases. PLoS One 2013; 8(9): e75091. https://doi.org/10.1371/journal.pone. 0075091

9. Rosengren LE, Karlsson JE, Sjögren M, Blennow K, Wallin A. Neurofilament protein levels in CSF are increased in dementia. Neurology 1999; 52(5): 1090-3. https://doi.org/ 10.1212/WNL.52.5.1090

10. Bridel C, van Wieringen WN, Zetterberg H, Tijms BM, Teunissen CE, Alvarez-Cermeño JC, et al. Diagnostic value of cerebrospinal fluid neurofilament light protein in neurology: a systematic review and meta-analysis. JAMA Neurol 2019; 76(9): 1035-48. https://doi.org/10.1001/jamaneurol. 2019.1534

11. Steinacker P, Semler E, Anderl-Straub S, Diehl-Schmid J, Schroeter ML, Uttner I, et al. Neurofilament as a blood marker for diagnosis and monitoring of primary progressive aphasias. Neurology 2017; 88(10): 961-9. https://doi.org/ 10.1212/WNL.0000000000003688

12. Zhao Y, Xin Y, Meng S, He Z, Hu W. Neurofilament light chain protein in neurodegenerative dementia: a systematic review and network meta-analysis. Neurosci Biobehav Rev 2019; 102: 123-38. https://doi.org/10.1016/j.neubiorev. 2019.04.014

13. Jin M, Cao L, Dai Y. Role of neurofilament light chain as a potential biomarker for Alzheimer's disease: a correlative meta-analysis. Front Aging Neurosci 2019; 11: 254. https://doi.org/10.3389/fnagi.2019.00254

14. Mattsson N, Insel PS, Palmqvist S, Portelius E, Zetterberg H, Weiner M, et al. Cerebrospinal fluid tau, neurogranin, and neurofilament light in Alzheimer's disease. EMBO Mol Med 2016; 8(10): 1184-96. https://doi.org/10.15252/emmm. 201606540

15. Kern S, Syrjanen JA, Blennow K, Zetterberg H, Skoog I, Waern M, et al. Association of cerebrospinal fluid neurofilament light protein with risk of mild cognitive impairment among individuals without cognitive impairment. JAMA Neurol 2019; 76(2): 187-93. https://doi.org/10.1001/ jamaneurol.2018.3459

16. Mattsson N, Andreasson U, Zetterberg H, Blennow K, Weiner MW, Aisen P, et al. Association of plasma neurofilament light with neurodegeneration in patients with Alzheimer disease. JAMA Neurol 2017; 74(5): 557-66. https://doi.org/10.1001/jamaneurol.2016.6117

17. Sánchez-Valle R, Heslegrave A, Foiani MS, Bosch B, Antonell A, Balasa M, et al. Serum neurofilament light levels correlate with severity measures and neurodegeneration markers in autosomal dominant Alzheimer's disease. Alzheimers Res Ther 2018; 10(1): 113. https://doi.org/ 10.1186/s13195-018-0439-y

18. Meeter LH, Dopper EG, Jiskoot LC, Sanchez-Valle R, Graff C, Benussi L, et al. Neurofilament light chain: a biomarker for genetic frontotemporal dementia. Ann Clin Transl Neurol 2016; 3(8): 623-36. https://doi.org/10.1002/ acn3.325
19. Weydt P, Oeckl P, Huss A, Müller K, Volk AE, Kuhle J, et al. Neurofilament levels as biomarkers in asymptomatic and symptomatic familial amyotrophic lateral sclerosis. Ann Neurol 2016; 79(1): 152-8. https://doi.org/10.1002/ ana.24552

20. Verde F, Steinacker P, Weishaupt JH, Kassubek J, Oeckl P, Halbgebauer $\mathrm{S}$, et al. Neurofilament light chain in serum for the diagnosis of amyotrophic lateral sclerosis. J Neurol Neurosurg Psychiatry 2019; 90(2): 157-64. https://doi.org/ 10.1136/jnnp-2018-318704

21. Gaiani A, Martinelli I, Bello L, Querin G, Puthenparampil M, Ruggero S, et al. Diagnostic and prognostic biomarkers in amyotrophic lateral sclerosis: neurofilament light chain levels in definite subtypes of disease. JAMA Neurol 2017; 74(5): 525-32. https://doi.org/10.1001/jamaneurol. 2016.5398

22. McCombe PA, Pfluger C, Singh P, Lim CYH, Airey C, Henderson RD. Serial measurements of phosphorylated neurofilament-heavy in the serum of subjects with amyotrophic lateral sclerosis. J Neurol Sci 2015; 353(1-2): 122-9. https://doi.org/10.1016/j.jns.2015.04.032

23. De Schaepdryver M, Jeromin A, Gille B, Claeys KG, Herbst V, Brix B, et al. Comparison of elevated phosphorylated neurofilament heavy chains in serum and cerebrospinal fluid of patients with amyotrophic lateral sclerosis. J Neurol Neurosurg Psychiatry 2018; 89(4): 367-73. https://doi.org/10.1136/jnnp-2017-316605

24. Gille B, De Schaepdryver M, Goossens J, Dedeene L, De Vocht J, Oldoni E, et al. Serum neurofilament light chain levels as a marker of upper motor neuron degeneration in patients with amyotrophic lateral sclerosis. Neuropathol Appl Neurobiol 2019; 45(3): 291-304. https://doi.org/10.1111/ nan.12511

25. Steinacker P, Feneberg E, Weishaupt J, Brettschneider J, Tumani H, Andersen PM, et al. Neurofilaments in the diagnosis of motoneuron diseases: a prospective study on $455 \mathrm{pa}-$ tients. J Neurol Neurosurg Psychiatry 2016; 87(1): 12-20. https://doi.org/10.1136/jnnp-2015-311387

26. Rossi D, Volanti P, Brambilla L, Colletti T, Spataro R, La Bella V. CSF neurofilament proteins as diagnostic and prognostic biomarkers for amyotrophic lateral sclerosis. J Neurol 2018; 265(3): 510-21. https://doi.org/10.1007/ s00415-017-8730-6

27. Menke RAL, Gray E, Lu CH, Kuhle J, Talbot K, Malaspina A, et al. CSF neurofilament light chain reflects corticospinal tract degeneration in ALS. Ann Clin Transl Neurol 2015; 2(7): 748-55. https://doi.org/10.1002/ acn 3.212

28. Tortelli R, Copetti M, Ruggieri M, Cortese R, Capozzo R, Leo A, et al. Cerebrospinal fluid neurofilament light chain levels: marker of progression to generalized amyotrophic lateral sclerosis. Eur J Neurol 2015; 22(1): 215-8. https://doi.org/10.1111/ene.12421

29. Lu CH, Macdonald-Wallis C, Gray E, Pearce N, Petzold A, Norgren N, et al. Neurofilament light chain: a prognostic biomarker in amyotrophic lateral sclerosis. Neurology 2015 ; 84(22): 2247-57. https://doi.org/10.1212/WNL. 0000000000001642

30. Benatar M, Wuu J, Andersen PM, Lombardi V, Malaspina A. Neurofilament light: a candidate biomarker of presymptomatic amyotrophic lateral sclerosis and phenoconversion. Ann Neurol 2018; 84(1): 130-9. https://doi.org/10.1002/ ana. 25276 
31. Vivithanaporn P, Heo G, Gamble J, Krentz HB, Hoke A, Gill MJ, et al. Neurologic disease burden in treated HIV/AIDS predicts survival: a population-based study. Neurology 2010; 75(13): 1150-8. https://doi.org/10.1212/ WNL.0b013e3181f4d5bb

32. McGuire JL, Gill AJ, Douglas SD, Kolson DL. Central and peripheral markers of neurodegeneration and monocyte activation in HIV-associated neurocognitive disorders. J Neurovirol 2015; 21(4): 439-48. https://doi.org/10.1007/ s13365-015-0333-3

33. Peluso MJ, Meyerhoff DJ, Price RW, Peterson J, Lee E, Young AC, et al. Cerebrospinal fluid and neuroimaging biomarker abnormalities suggest early neurological injury in a subset of individuals during primary HIV infection. J Infect Dis 2013; 207(11): 1703-12. https://doi.org/10.1093/infdis/ jit088

34. Krut JJ, Mellberg T, Price RW, Hagberg L, Fuchs D, Rosengren L, et al. Biomarker evidence of axonal injury in neuroasymptomatic HIV-1 patients. PLoS One 2014; 9(2): e88591. https://doi.org/10.1371/journal.pone. 0088591

35. Peterson J, Gisslen M, Zetterberg H, Fuchs D, Shacklett BL, Hagberg L, et al. Cerebrospinal fluid (CSF) neuronal biomarkers across the spectrum of HIV infection: hierarchy of injury and detection. PLoS One 2014; 9(12): e116081. https://doi.org/10.1371/journal.pone.0116081

36. Abdulle S, Mellgren Å, Brew BJ, Cinque P, Hagberg L, Price RW, et al. CSF neurofilament protein (NFL) - a marker of active HIV-related neurodegeneration. J Neurol 2007; 254(8): 1026-32. https://doi.org/10.1007/ s00415-006-0481-8

37. Rosengren LE, Karlsson J-E, Karlsson J-O, Persson LI, Wikkelsø C. Patients with amyotrophic lateral sclerosis and other neurodegenerative diseases have increased levels of neurofilament protein in CSF. J Neurochem 2002; 67(5): 2013-8. https://doi.org/10.1046/j.1471-4159. 1996.67052013.x

38. Cai L, Huang J. Neurofilament light chain as a biological marker for multiple sclerosis: a meta-analysis study. Neuropsychiatr Dis Treat 2018; 14: 2241-54.https://doi.org/ 10.2147/NDT.S173280

39. Domingues RB, Fernandes GBP, Leite FBVDM, Senne C. Neurofilament light chain in the assessment of patients with multiple sclerosis. Arq Neuropsiquiatr 2019; 77(6): 436-41. https://doi.org/10.1590/0004-282x20190060

40. Siller N, Kuhle J, Muthuraman M, Barro C, Uphaus T, Groppa $\mathrm{S}$, et al. Serum neurofilament light chain is a biomarker of acute and chronic neuronal damage in early multiple sclerosis. Mult Scler J 2019; 25(5): 678-86. https://doi.org/10.1177/1352458518765666

41. Burman J, Zetterberg H, Fransson M, Loskog AS, Raininko R, Fagius J. Assessing tissue damage in multiple sclerosis: a biomarker approach. Acta Neurol Scand 2014; 130(2): 81-9. https://doi.org/10.1111/ane.12239

42. Barro C, Leocani L, Leppert D, Comi G, Kappos L, Kuhle J. Fluid biomarker and electrophysiological outcome measures for progressive MS trials. Mult Scler 2017; 23(12): 1600-13. https://doi.org/10.1177/1352458517732844

43. Kuhle J, Disanto G, Lorscheider J, Stites T, Chen Y, Dahlke F, et al. Fingolimod and CSF neurofilament light chain levels in relapsing-remitting multiple sclerosis. Neurology 2015; 84(16): 1639-43. https://doi.org/10.1212/ WNL.0000000000001491
44. Khalil M, Enzinger C, Langkammer C, Ropele S, Mader A, Trentini A, et al. CSF neurofilament and $\mathrm{N}$-acetylaspartate related brain changes in clinically isolated syndrome. Mult Scler J 2013; 19(4): 436-42. https://doi.org/10.1177/ 1352458512458010

45. Bhan A, Jacobsen C, Myhr KM, Dalen I, Lode K, Farbu E. Neurofilaments and 10-year follow-up in multiple sclerosis. Mult Scler J 2018; 24(10): 1301-7. https://doi.org/10.1177/ 1352458518782005

46. Filippi P, Vestenická V, Siarnik P, Sivakova M, Čopíková-Cudráková D, Belan V, et al. Neurofilament light chain and MRI volume parameters as markers of neurodegeneration in multiple sclerosis. Neuro Endocrinol Lett 2020; 41(1): 17-26.

47. Gunnarsson M, Malmeström C, Axelsson M, Sundström P, Dahle C, Vrethem M, et al. Axonal damage in relapsing multiple sclerosis is markedly reduced by natalizumab. Ann Neurol 2011; 69(1): 83-9. https://doi.org/10.1002/ ana. 22247

48. Novakova L, Zetterberg H, Sundström P, Axelsson M, Khademi M, Gunnarsson M, et al. Monitoring disease activity in multiple sclerosis using serum neurofilament light protein. Neurology 2017; 89(22): 2230-7. https://doi.org/ 10.1212/WNL.0000000000004683

49. Byrne LM, Rodrigues FB, Blennow K, Durr A, Leavitt BR, Roos RAC, et al. Neurofilament light protein in blood as a potential biomarker of neurodegeneration in Huntington's disease: a retrospective cohort analysis. Lancet Neurol 2017; 16(8): 601-9. https://doi.org/10.1016/S14744422(17)30124-2

50. Niemelä V, Landtblom AM, Blennow K, Sundblom J. Tau or neurofilament light - which is the more suitable biomarker for Huntington's disease? PLoS One 2017; 12(2): e0172762. https://doi.org/10.1371/journal.pone.0172762

51. Johnson EB, Byrne LM, Gregory S, Rodrigues FB, Blennow K, Durr A, et al. Neurofilament light protein in blood predicts regional atrophy in Huntington disease. Neurology 2018; 90(8): e717-23. https://doi.org/10.1212/ WNL.0000000000005005

52. Brettschneider J, Petzold A, Süßmuth SD, Landwehrmeyer GB, Ludolph AC, Kassubek J, et al. Neurofilament heavy-chain $\mathrm{NfH}^{\mathrm{SM} 35}$ in cerebrospinal fluid supports the differential diagnosis of Parkinsonian syndromes. Mov Disord 2006; 21(12): 2224-7. https://doi.org/ 10.1002/mds. 21124

53. Hansson O, Janelidze S, Hall S, Magdalinou N, Lees AJ, Andreasson U, et al. Blood-based NfL: a biomarker for differential diagnosis of Parkinsonian disorder. Neurology 2017; 88(10): 930-7. https://doi.org/10.1212/ WNL.0000000000003680

54. Sajjadi SA, Acosta-Cabronero J, Patterson K, Diaz-de-Grenu LZ, Williams GB, Nestor PJ. Diffusion tensor magnetic resonance imaging for single subject diagnosis in neurodegenerative diseases. Brain 2013; 136(Pt 7): 2253-61. https://doi.org/10.1093/brain/awt118

55. Lin YS, Lee WJ, Wang SJ, Fuh JL. Levels of plasma neurofilament light chain and cognitive function in patients with Alzheimer or Parkinson disease. Sci Rep 2018; 8(1): 17368. https://doi.org/10.1038/s41598-018-35766-w

56. Staffaroni AM, Kramer AO, Casey M, Kang H, Rojas JC, Orrú CD, et al. Association of blood and cerebrospinal fluid tau level and other biomarkers with survival time in sporadic Creutzfeldt-Jakob disease. JAMA Neurol 2019; 
76(8): 969-77. https://doi.org/10.1001/jamaneurol. 2019.1071

57. Steinacker P, Blennow K, Halbgebauer S, Shi S, Ruf V, Oeckl P, et al. Neurofilaments in blood and CSF for diagnosis and prediction of onset in Creutzfeldt-Jakob disease. Sci Rep 2016; 6(1): 1-6. https://doi.org/10.1038/srep38737

58. Zerr I, Schmitz M, Karch A, Villar-Piqué A, Kanata E, Golanska E, et al. Cerebrospinal fluid neurofilament light levels in neurodegenerative dementia: evaluation of diagnostic accuracy in the differential diagnosis of prion diseases. Alzheimers Dement 2018; 14(6): 751-63. https://doi.org/ 10.1016/j.jalz.2017.12.008

59. Tiedt S, Duering M, Barro C, Boeck AGJ, Bode FJ, Klein M, et al. Serum neurofilament light a biomarker of neuroaxonal injury after ischemic stroke. Neurology 2018 91(14): E1338-47. https://doi.org/10.1212/WNL. 0000000000006282

60. Rana OR, Schröder JW, Baukloh JK, Saygili E, Mischke K, Schiefer J, et al. Neurofilament light chain as an early and sensitive predictor of long-term neurological outcome in patients after cardiac arrest. Int J Cardiol 2013; 168(2): 1322-7. https://doi.org/10.1016/j.ijcard.2012.12.016
V. Taluntienė, R. Motiekaitytė, R. Kizlaitienè, N. Giedraitienė, G. Kaubrys

THE ROLE OF NEUROFILAMENT LIGHT CHAIN IN THE CONTEXT OF NEUROLOGICAL DISORDERS

\section{Summary}

Neurofilament light chain (NFL) is a structural neuronal protein highly expressed in large myelinated axons. Axonal damage leads to increased NFL levels in cerebrospinal fluid and blood. Therefore, it could be a potential diagnostic biomarker for various neurological disorders, especially caused by neurodegeneration and inflammation. New sensitive immunoassays for NFL measurement in the blood offer possibilities of monitoring disease progression and assessing treatment response. An increasing amount of data suggests that NFL could also be a prognostic marker for many disorders. The purpose of this article is to review the literature on the role of NFL in the context of dementia, amyotrophic lateral sclerosis, HIV-associated neurocognitive disorders, multiple sclerosis, and other neurological diseases.

Keywords: neurofilament light chain, axonal damage, neurodegeneration, multiple sclerosis.

Gauta:

20200819

Priimta spaudai: 20201001 